\title{
Central Nervous System Depressant Effects of the Methanolic Leaves Extracts of Tabernaemontana divaricata
}

\author{
Md. Omor Faruq, Mst. Shirajum Munira*, Sonia Zaman, Sabiha Ferdowsy Koly, \\ Rayhanus Salam, Sonia Rani Das, Md. Anisur Rahaman \\ Department of Pharmacy, Southeast University, Dhaka, Bangladesh
}

*Corresponding Author: Mst. Shirajum Munira, Department of Pharmacy, Southeast University, Dhaka, Bangladesh

\begin{abstract}
Tabernaemontana divaricata(TD) (family: Apocynaceae) has remarkable medicinal value. Traditionally the plant is used as an emmenagogue, aphrodisiac, tonic, purgative, tonic to the brain, the liver and spleen. Considering the important activities reported in traditional uses, aim of the present study was to assess the effect of methanolic extract of TD leaves on the central nervous system (CNS) in mice. The CNS depressant activity was assessed by open field and hole cross test while anti-depressant activity was evaluated by tail suspension and force swimming test. Two dose 200 and $400 \mathrm{mg} / \mathrm{kg}$ body weight were used for this purpose.A statically significantly decreases in locomotor activity at dose of 200 and $400 \mathrm{mg} / \mathrm{kg}$ was observed. The extracts, at the dose of $400 \mathrm{mg} / \mathrm{kg}$ body weight, were shown to have better effect than $200 \mathrm{mg} / \mathrm{kg}$. The results demonstrated that, the extract of TD leaves had the potential phytomedicine value for its significant CNS depressant properties.
\end{abstract}

Keywords: open field, hole cross, tail suspension, force swimming, CNS depressant, Tabernaemontana divaricata.

\section{INTRODUCTION}

GABA is the chief inhibitory amino acid transmitter of central nervous system and it is present in some $25-50 \%$ of all neurones [1]. Different anxiolytic, muscle relaxant, sedative-hypnotic drugs are elucidated their action through GABA, therefore it is possible that extracts of T.divaricata may acts by potentiating GABAergic inhibition in the CNS via membrane hyperpolarization resulting in a decrease in the firing rate of critical neurons in the brain or may be due to direct activation of GABA receptor by the extracts[2].

Theutilize of the medicinal plants is rising in many countries where $35 \%$ of drugs contain natural element. At present, thousands of plant metabolites are being successfully applied for the treatment of variety of ailments [3]. The study of the efficacy of plant-based drugs used in the traditional medicine have been paid great attention because they are cheap, have little side effects [4] . In Bangladesh thousands of species are known to have medicinal value and the use of different parts of several medicinal plants to cure specific ailments has been in vogue since ancient times. Obsession on modern medicinal system leads people to an alternative approach to improve and maintain good health is increased tremendously by using medicinal herb over the last centuries. Many of the modern days important drugs and processed medicines are of plant origin[5].The beneficial medicinal effects of plant materials typically results from combinations of secondary product present in plant such as alkaloids, steroids, tannins, phenol compounds, resins, gums, flavonoids and fatty acids which are capable of producing definite physiological action on body [6].

Tabernaemontana divaricata belongs to the family of Apocynaceae, found in Asia, Africa, Australia, North and South America and a wide assortment of oceanic islands. Experimentally, T. divaricata are shown to possess reversible acethylcholinesterase inhibitory effect/roots part[7], anti fertility Activity/leaves[8],antioxidant and anti-Inflammatory/ flowers part [9,10,11], gastroprotective/ flowers[12], antidiabetic and cytotoxic/flowers[13,14], antinociceptive /leaves[15], anticonvulsant/ flowers [16], antibacterial [17], antiulcerogenic / flowers part [11], anthelmintic / leaves part. [18], anti-Obesity / leaves part [19], aemostatic potential/Latex Proteases [20], anticancer/flowers [21], 
cardiovascular effects/roots [22], Inhibition of obsessive compulsive behavior/Leaves [23], antiproliferative/roots and barks [24] effects.

Previously it has been reported that various parts of plants such as leaves, stems, and roots contain chemical constituents such as alkaloids, terpenoids, steroids, flavonoids, phenyl propanoids, phenolic acids and enzymes[25,26,27,28].Study of roots and stems of T.divaricata isolated six compounds: bis (2, 3-dihydroxypropyl) octacosanedioate, tetratriacontanol, palmitic acid, glycerol monopalmitate, Bsitosterol and B-daucosterol. [29]. At least 66 alkaloids have been isolated from T. divaricata [30]. Its folklore usage is as an emmenagogue, aphrodisiac, tonic, purgative, tonic to the brain, the liver and spleen. It is used in the treatment of paralysis, weakness of the limbs, cures scorpion-sting and epilepsy. The oil is beneficial for epilepsy (Yunani) [16].

To the best of our knowledge, no scientific data regarding the neuropharmacological effect on Hole cross method, Tail suspension test, and Forced swimming test of $T$. divaricata leaves have been found. Thus the present study was undertaken to evaluate the neuropharmacological effect of methanolic extract of $T$. divaricata leaves.

\section{Materials AND MethodS}

\subsection{Plant Materials and Extraction}

Tabernaemontana divaricata (TD) were collected from the adjacent area Feni, Bangladesh during October 2017. The plant material was taxonomically identified by the National Herbarium of Bangladesh. Its voucher specimen no 45254. maintained in our laboratory for future reference.

Powdered plant materials (Flowers) having a weight of $350 \mathrm{gm}$ were taken in an amber colored reagent bottle and soaked in methanol. The bottle with its contents were sealed and kept for a period of about 7 days with occasional shaking and stirring. The whole mixture was then filtered through cotton and then through what man No.1 filters paper and was concentrated with a rotary evaporator under reduced pressure at $55^{\circ} \mathrm{C}$ temperature to afford crude extract.

\subsection{Animals}

Swiss albino mice (25-30g) were used for assessing biological activity. The animals were maintained under standard laboratory conditions .The animals were allowed to adjust to the environment for 10 days prior to experimental session. The animals were divided into different groups, each consisting of five animals which were fasted overnight prior to the experiments. Experiments on animals were performed in accordance with guidelines of the Institutional Animal Ethics Committee, Southeast University, Dhaka, Bangladesh. Animal treatment and maintenance for analgesic effects were conducted in accordance with the Principle of Laboratory Animal Care (NIH publication No. 85-23, revised 1985) and apply Guidelines of Southeast University, Dhaka, Bangladesh.

\subsection{Drugs and Chemicals}

Diazepam and Diclofenac Sodium were obtained from Square Pharmaceuticals Company Ltd, Bangladesh. Nortriptyline was obtained from Navana Pharmaceuticals Limited, Bangladesh. Acetic acid was purchased from Merck, Germany. Normal saline water $(0.9 \% \mathrm{NaCl})$, a creation of Beximco Infusion Company Ltd., Bangladesh was purchased from local market.

\subsection{Neuropharmacological Test}

\subsubsection{Open Field Test}

The experiment was carried out following the methods described by Wash and Cummins [31]. This experiment evaluates a range of anxiety-induced, locomotor activity and exploratory actions of rodents [32].The animals were divided into four groups with five mice in each group. Group I animals received vehicle (saline water, $10 \mathrm{ml} / \mathrm{kg}$ body weight), animals of Group II received Diazepum at 1 $\mathrm{mg} / \mathrm{kg}$ body weight while animals of Group III, IV were treated with 200 and $400 \mathrm{mg} / \mathrm{kg}$ body weight (p.o.) of the TD leaves extract. The floor of an open field of half square meter was separated into a series of squares. Every squares alternatively colored black and white. The tools had $40 \mathrm{~cm}$ height a wall. Total number of squares visited by mice was computed for $3 \mathrm{~min}$ on 30, 60, 90 and $120 \mathrm{~min}$ after oral administration of test samples. 


\subsubsection{Hole Cross Test}

It was described by Takagi [33]. A cage having a size of $30 \times 20 \times 14 \mathrm{~cm}$ with a steel partition fixed at the middle. A hole of $3 \mathrm{~cm}$ diameter was made at a height of $7.5 \mathrm{~cm}$ in the middle of the cage. The animals were segregated into different group and each group contain 5 animals. The control group received vehicle (saline water) whereas the test group received $T$. divaricata extracts (at the doses of 200 and $400 \mathrm{mg} / \mathrm{kg}$ p.o.) and standard group received diazepam at the dose of $1 \mathrm{mg} / \mathrm{kg}$ body weight orally. Each mice was then placed on one side of the chamber and the number of passages of each mice through the hole from one chamber to other was recorded for $3 \mathrm{~min}$ on 30, 60, 90 and $120 \mathrm{~min}$ during the study period.

\subsubsection{Tail Suspension Test}

The tail suspension test is commonly used to measure the effects of psychotropic drugs, such as antidepressants, in mice [34]. Briefly, mice both acoustically and visually isolated were hold $30 \mathrm{~cm}$ above the floor by adhesive tape placed approximately $1-2 \mathrm{~cm}$ from the tip of the tail. During a $5 \mathrm{~min}$ period, Immobility time was recorded. Mice were considered immobile only when they hung passively or stayed completely motionless. Conventional antidepressant drugs decrease the immobility time in this test. The animals were treated with the plant extract (200 and $400 \mathrm{mg} / \mathrm{kg})$, nortriptyline or vehicle, $45 \mathrm{~min}$ before the test.

\subsubsection{Forced Swimming Test}

Forced swimming test is important for showing of antidepressant activity. It is the most widely used pharmacological model for measuring antidepressant activity. This method is based on the observation of animals exposed to a situation of forced swimming. In this test, animals become passive and immobile after a period of forceful activity, producing only the movements required to keep their heads above the water. This test was carried out on mice according to the method of Porsolt [35].Swimming sessions were performed by placing the animals in individual Plexiglas's cylinders (40 cm high, $24 \mathrm{~cm}$ diameter) containing $20 \mathrm{~cm}$ of water. The animals were treated with the extract (200 and $400 \mathrm{mg} / \mathrm{kg}$ ), nortriptyline $(1 \mathrm{mg} / \mathrm{kg}$ ) or vehicle. Treatments were occurred before 45 minute of the test. All animals were forced to swim for $6 \mathrm{~min}$, and the time spent in immobility during the last 5 min of a 6 min observation period was traced. A decrease in the duration of immobility in the forced swimming test indicates antidepressant activity. The period between when the mouse was immersed and when no further attempts to escape were made (apart from the movements necessary to keep its head above the water) was recorded as the immobility time.

\section{Results}

\subsection{CNS Test}

\subsubsection{Open Field Test}

In the Open field test, T.divaricata extracts exhibited a decrease in the movements of the test animals at all dose levels tested. They were statistically significant $(\mathrm{P}<0.05)$ for all dose levels and followed a dose-dependent response (Table1).

Table1. Effect of methanolic extract of the Tabernaemontana divericata leaves extract on open field test in mice

\begin{tabular}{|c|c|c|c|c|c|}
\hline \multirow[t]{2}{*}{ Group } & \multirow[t]{2}{*}{ Dose } & \multicolumn{4}{|c|}{ Number of Movements } \\
\hline & & $30 \mathrm{~min}$ & $60 \mathrm{~min}$ & $90 \mathrm{~min}$ & $120 \mathrm{~min}$ \\
\hline Group-I & Vehicle & $136.6 \pm 3.91$ & $115.25 \pm 5.52$ & $86.2 \pm 6.92$ & $90.25 \pm 7.43$ \\
\hline Group-II & $1 \mathrm{mg} / \mathrm{kg}$ & $88.75 \pm 4.5$ & $54.25 \pm 6.53$ & $19.5 \pm 4.5^{*}$ & $6.5 \pm 1.10^{*}$ \\
\hline Group-III & $200 \mathrm{mg} / \mathrm{kg}$ & $118 \pm 5.25$ & $65.25 \pm 6.13$ & $45 \pm 8.81 *$ & $33.25 \pm 3.99 *$ \\
\hline Group-IV & $400 \mathrm{mg} / \mathrm{kg}$ & $75.75 \pm 6.60$ & $62 \pm 3.25$ & $37.25 \pm 3.83^{*}$ & $30 \pm 2.16^{*}$ \\
\hline
\end{tabular}

Values are mean $\pm S D,(n=5)$. Dunnet test as compared to vehicle control. Group I animals received vehicle (saline water), Group II received diazepam $1 \mathrm{mg} / \mathrm{kg}$ body weight, Group III and Group IV were treated with 200 and $400 \mathrm{mg} / \mathrm{kg}$ body weight (p.o.) of the the methanolic extract of Tabernaemontana divericata leaves. 


\subsubsection{Hole-Cross Test}

In the Hole-cross test, the effect of methanolic extract of T. divaricata on mice has been shown in (Table-2). T. divericata extracts showed a drop off in the movements of the test animals at all dose levels tested. They were statistically significant $(\mathrm{P}<0.05)$ for all dose levels and followed a dosedependent response. The depressing effect was most intense during the $90 \mathrm{~min}$ and $120 \mathrm{~min}$ observation periods.

Table2. Effect of methanolic extract of the Tabernaemontana divericata on hole cross test in mice

\begin{tabular}{|l|l|l|l|l|l|}
\hline \multirow{2}{*}{ Group } & \multirow{2}{*}{ Number of Movements } & \multicolumn{3}{l|}{} \\
\cline { 3 - 6 } & Dose & $30 \mathrm{~min}$ & $60 \mathrm{~min}$ & $90 \mathrm{~min}$ & $120 \mathrm{~min}$ \\
\hline Group- I & Vehicle & $13.5 \pm 1.2$ & $14.25 \pm 1.2$ & $15 \pm 1.5$ & $14.25 \pm 1$ \\
\hline Group- II & $1 \mathrm{mg} / \mathrm{kg}$ & $0.25 \pm 0.5^{*}$ & $1 \pm 0^{*}$ & $0.75 \pm 0.9^{*}$ & $0.75 \pm 0.95^{*}$ \\
\hline Group- III & $200 \mathrm{mg} / \mathrm{kg}$ & $8.25 \pm 1.54$ & $5.5 \pm 0.5^{*}$ & $5 \pm 1.08^{*}$ & $3.75 \pm 0.44^{*}$ \\
\hline Group- IV & $400 \mathrm{mg} / \mathrm{kg}$ & $7.75 \pm 1.7$ & $5.5 \pm 1.29^{*}$ & $4.5 \pm 0.4^{*}$ & $3.6 \pm 0.5^{*}$ \\
\hline
\end{tabular}

Values are mean $\pm \mathrm{SD},(\mathrm{n}=5) ; * \mathrm{p}<.05$, Dunnet test as compared to vehicle control. Group I animals received vehicle (saline water), Group II received diazepam $1 \mathrm{mg} / \mathrm{kg}$ body weight, Group III and Group IV were treated with 200 and $400 \mathrm{mg} / \mathrm{kg}$ body weight (p.o.) of the METD.

\subsubsection{Tail Suspension Test}

In the tail suspension test, the methanol extract of T. divaricata leaves showed no significant result in comparison with the positive control, nortriptyline \& that's why it can be assumed that extract has depressive effect (Table 3 ).

Table3. Effect of methanolic extract of the Tabernaemontana divericata leaves on tail suspension test in mice

\begin{tabular}{|l|l|l|}
\hline Group & Dose $(\mathrm{mg} / \mathrm{kg})$ & Immobility time(S) \\
\hline Group-I & Vehicle & $132.5 \pm 8$ \\
\hline Group-II & 1 & $64.25 \pm 10^{*}$ \\
\hline Group-III & 200 & $126.5 \pm 14$ \\
\hline Group-IV & 400 & $135.5 \pm 8$ \\
\hline
\end{tabular}

Values are mean \pm SEM, $(n=5) ;{ }^{*} \mathrm{p}<.05$ Dunnet test as compared to vehicle control .Group I animals received vehicle (saline water), Group II received Nortriptylene $1 \mathrm{mg} / \mathrm{kg}$ body weight, Group III and IV were treated with 200 and $400 \mathrm{mg} / \mathrm{kg}$ body weight (p.o.) of Tabernaemontana divericata leaves extract.

\subsubsection{Forced Swimming Test}

In the forced swimming test, T. divaricata extracts exhibited a decrease in the movements of the test animals at all dose levels tested. That's why it can be said that extract has depressive effect (Table 4).

Table4. Effect on methanolic extract of the Tabernaemontana divericata on forced swimming test

\begin{tabular}{|l|l|l|}
\hline \multicolumn{1}{|c|}{ Group } & Dose $(\mathrm{mg} / \mathrm{kg})$ & Immobility time(sec) \\
\hline Group I & Vehicle & $118.5 \pm 4.33$ \\
\hline Group II & 1 & $70.5 \pm 10.34 *$ \\
\hline Group III & 200 & $95,75 \pm 5.67$ \\
\hline Group IV & 400 & $158.5 \pm 8.08 *$ \\
\hline
\end{tabular}

Values are mean $\pm \mathrm{SD},(\mathrm{n}=5) ;{ }^{*} \mathrm{p}<.05$ as compared to vehicle control. Group I animals received vehicle (saline water), Group II received Nortriptylene $1 \mathrm{mg} / \mathrm{kg}$ body weight, Group III and IV were treated with 200 and $400 \mathrm{mg} / \mathrm{kg}$ body weight (p.o.) of Tabernaemontana divericata leaves extract. METD=Methanolic extract of Tabernaemontana divaricata

\section{DISCUSSION}

The present study investigated the behavioral effects of the methanolic leaves extracts of TD in mice. For anxiolytic test we used two methods- open field test and hole cross test. From both methods we observed that TD extracts produced significant depressant-like effects. In open field method, the extract showed a decrease in locomotion in the test animals at both dose levels $(200$ and $400 \mathrm{mg} / \mathrm{kg}$ 
body weight). The depressant activity was most prominent during third (90 min) and fourth period (120 min) and statistically significant.

In the hole cross test, the extract also showed a decrease in locomotion in the test animals at both dose levels (200 and $400 \mathrm{mg} / \mathrm{kg}$ body weight) and was statistically significant $(0.05)$.

We also used forced swimming test and Tail emulsion test to check anti depressant-like effects. But both doses of TD extracts did not produce significant anti depressant effect.

When assessed in Tail Suspension Test (TST), we noticed that after oral administration of varying doses $(200$ and $400 \mathrm{mg} / \mathrm{kg}$ ) of TD methanolic extracts immobility time was increased compared to standard nortriptylene (antidepressant) drugs .Even at $400 \mathrm{mg} / \mathrm{kg}$ dose of our extracts immobility time was increased higher than control group. Similar result happened on forced swimming test. At both doses of 200 and $400 \mathrm{mg} / \mathrm{kg}$, the extract showed higher immobility time than the standard. Based on the these findings, it can be suggested that the extracts have depressant effect which supports the earlier report had been done by another method. The report said that TD has depressive effects on both peripheral and central nervous systems [36].Previously it was also reported that TD (ethanolic and aqueous extracts) showed anticonvulsant activity against maximal electroshock (MES)-induced convulsion which also supports our findings [22].

Locomotor activity considered as an increase in alertness and decrease in locomotor activity indicated sedative effect [37]. Extracts of T.divaricata decreased locomotor activity indicates its CNS depressant activity. Many research showed that plant containing flavonoids, saponins and tannins are useful in many CNS disorders [38]. Earlier investigation on phytoconstituents and plants suggests that many flavonoids and neuroactive steroids were found to be ligands for the $\mathrm{GABA}_{\mathrm{A}}$ receptors in the central nervous system; which led to assume that they can act as benzodiazepine like molecules [37]. Phytochemical investigations also showed the presence of alkaloids, flavonoids, steroid and tannins in the extracts, so might be this phytoconstituents are responsible for its CNS depressant activity.

\section{CONCLUSION}

Our findings confirmed the depressant activity of Tabernaemontana divaricata.From the study it may be concluded that the test drug can be replaced as an alternative agent in preventing and treating the anxiety. However, further studies are needed to evaluate the safety profile of the plant as safe and therapeutic depressant agent.

\section{ACKNOWLEDGEMENT}

I express my sincere thanks and gratitude to Dr. Siddiqul Islam, Chairman, Department of Pharmacy, Southeast University, Banani, Dhaka, Bangladesh for providing laboratory facilities and necessary reagents support while doing the study.

\section{REFERENCES}

[1] Fagg G.E. and Foster A.C., Amino acid neurotransmitters and their pathways in the mammalian central nervous system, Neuroscience, 1983, 9:701-719.

[2] Koblyakov V.A., Free radicals and inflammation (progress in inflammation research series), Biochem, 2001, 66: 937-938.

[3] Rakh M.S. and Chaudhari S.R., Evaluation of CNS depressant activity of Momordica dioica Roxb willd fruit pulp, International Journal of Pharmacy and Pharmaceutical Sciences, 2010, 2:124-126.

[4] Kumara N., Identification of strategies to improve research on medicinal plants used in SriLanka in Proceedings of the WHO Symposium, University of Ruhuna, Galle, Sri Lanka, 2001, pp. 12-14.

[5] Thomas S., Patil D. A., Patil A. G. And Naresh C., Pharmacognostic evaluation and physicochemical analysis of an Averrhoa carambola L.Fruit, Journal of Herbal Medicine and Toxicology, 2008, 2( 2):51-54.

[6] Joshi B., Lekhak S. and Sharma A., Antibacterial property of different medicinal plants: Ocimum sanctum, Cinnamomum zeylanicum, Xanthoxylum armatum and Origanum majorana, Journal of Science Engineering and Technology, 2009, 5: 143-150.

[7] Pratchayasakul W., Pongchaidecha A., Chattipakorn N. And Chattipakorn S. C., Reversible acetylcholinesterase inhibitory effect of Tabernaemontana divaricata extract on synaptic transmission in rat CA1 hippocampus, The Indian journal of medical research, 2010,131:411-7. 
[8] Sachin Jain and Avijeet Jain, Evaluation of anti-fertility activity of Tabernaemontana divaricata (Linn) R.Br. leaves in rats . Natural Product Research, 2010, 24:855- 860.

[9] Thambi P.T., Kuzhivelil B., Sabu M.C. and jolly C.I., Antioxidant and antiinflammatory activities of the flowers of Tabernaemontana coronaria, Indian Journal of Pharmaceutical Sciences, 2006, 68(3): 352-355.

[10] Qamruzzama, Ansari J.A. and Sayyed M., Analgesic and Anti-inflammatory Effect of Ethanolic Extract of Tabernaemontana divaricata L.Flowers in Rats, Der Pharmacia Lettre, 2012,4(5):1518-1522.

[11] Ali Khan M.S., Mat Jais A.M., and Afreen A., Prostaglandin Analogous and Antioxidant Activity Mediated Gastroprotective Action of Tabernaemontana divaricata (L.)Flower Methanolic Extract against Chemically Induced Gastric Ulcers in Rats, BioMed research International. 2013,pp1-18.

[12] Ali Khan M.S., Gastroprotective Effect of Tabernaemontana divaricata (Linn.) Flower Methanolic Extract in Wistar Rats. British Journal of Pharmaceutical Research, 2011, 1(3):88-98.

[13] Neimkhum W., Niwatananun W., Yotsawimonwat S., and Okonogi S., Biological Activities of Active Extracts from Stem of Tabernaemontana Divaricata, Journal of Metals ,Materials and Minerals, 2010, 20 (No.3):201-206.

[14] Rahman M.M., Sayeed M.A., Biplab K.P., Siddique S.A., Antidiabetic and cytotoxic activities of methanolic extract of Tabernaemontana divaricata (L.) leaves in alloxan induced mice, Asian Journal of Pharmaceutical and Clinical Research, 2012, 5(1): 49-52.

[15] Sharker S.M., Chakma S. and Rahman A.A., Phytochemical and antinociceptive study of leaves of Tabernaemontana divaricata (L), Journal of Medicinal Plants Research, 2011, 5(2):245-247.

[16] Basavaraj P, Shivakumar B, Shivakumar H, Manjunath V.J., Evaluation of anticonvulsant activity of Tabernaemontana divaricata (LINN) R. BR. flower extract, International Journal of Pharmacy and pharmaceutical science, 2011,3(3):310-315.

[17] Gopinath S.M., Suneetha T.B., Mruganka V.D., Ananda S., Evaluation of antibacterial activity of Tabernaemontana divaricata (L.) leaves against the causative organisms of Bovine mastitis, International Journal of Research in Phytochemistry and Pharmacology, 2011,1(4):211-213.

[18] Pushpa B., Latha K.P., Vaidya V.P., Shruthi A. and Shweath C., In vitro Anthelmintic activiy of Leaves extracts of Tabernaemontana coronaria. International Journal of ChemTech Research, 2011, 3: 1788-1790.

[19] Kanthlal S.K., Suresh V., Arunachalam G., Royal Frank P., Kameshwaran, Anti obesity and hypolipidemic activity of methanolic extract of Tabernaemontana divaricata on atherogenic diet induced obesity. International Research Journal of Pharmacy. 2012, 3(3):157-161.

[20] Singh M.K., Usha R., Hithayshree K.R. and Bindhu O.S., Hemostatic potential of latex proteases from Tabernaemontana divaricata (L.) R. Br. ex. Roem. and Schult. and Artocarpus altilis (Parkinson ex. F.A. Zorn) Forsberg. Journal of thrombosis and thrombolysis, 2015, 39(1):43-9.

[21] Dantu A.S., Shankarguru P., Devi D.R., Vedha Hari B.N., Evaluation of in vitro anticancer activity of hydroalcoholic extract of Tabernaemontana divaricata, Asian Journal of Pharmaceutical and clinical Clinical Research, 2012, 5:59-61.

[22] Chanchal N. Raja, A. Balasubramaniamb, Sayyed Nadeem , Anticonvulsant activity of Tabernaemontana divaricata extract in experimental mice, J. Nat. Prod. Plant Resour, 2014,4 (1):64-68.

[23] Chanchal N. Raja, A Balasubramaniam, Navin R., Sayyed Nadeem, Tabernaemontana divaricata leaves extract exacerbate burying behavior in mice, Avicenna journal of Phytomedicine, 5:282-287.

[24] Kumar A. and Selvakumar S., Antiproliferative efficacy of Tabernaemontana divaricata against HEP2 cell line and Vero cell line, Pharmacognosy Magazine, 2015, 11:46-52.

[25] Arambewela LSR, Ranatunge T. Indole alkaloid from Tabernaemontana divaricata. Phytochemistry 1991; 3: $1740-1$.

[26] Kam TS, Anuradha S. Alkaloids from Tabernaemontana divaricata. Phytochemistry 1995; 4 : 313-6.

[27] Fulton DC, Kroon PA, Threlfall DR. Enzymological aspects of the redirection of terpenoid biosynthesis in elicitor-treated cultures of Tabernaemontana divaricata. Phytochemistry 1994; 35: 1183-6.

[28] Sierra MI. Biochemical, molecular and physiological aspects of plant peroxidases. Geneva: Imprimerie National 1991

[29] Shuang L., Hai-sheng C., Hou-peng W., JIN Li, Li-ming Q., LU Jia, Study on chemical constituents of Tabernaemontana divaricata, Academic Journal of Second Military Medical University, 2007-04.

[30] Nakdook W., Khongsombat O., Taepavarapruk P., Taepavarapruk N. and Ingkaninan K., The effects of Tabernaemontana divaricata root extract on amyloid beta-peptide 25-35 peptides induced cognitive deficits in mice, 2010, Journal of ethnopharmacology, 130(1):122-6.

[31] Walsh R. N., R. A. Cummins, The open-field test: a critical review, Psychological Bulletin, 1976, 83:482504. 
[32] Farhana Alam Ripa, Pritesh Ranjan Dash and Md. Omar Faruk, CNS depressant, analgesic and antiinflammatory activities of methanolic seed extract of Calamus rotang Linn. fruits in rat, Journal of Pharmacognosy and Phytochemistry, 2015, 3(5): 121-125.

[33] Takagi K., Watanabe M., Saito H., Studies on the spontaneous movement of animals by the hole cross test: Effect of 2-dimethylaminoethane and Its acyl esters on the central nervous system, Japanese Journal of Pharmacology, 1971, 21:797-810.

[34] Steru L., Chermat R., Thierry B., Simon P., Tail suspension test: A new method for screening antidepressants in mice, Psychopharmacology, 1985, 85:367-370.

[35] Porsolt R. D., Bertin A. and Jalfre M., Behavioral despair in mice: a primary screening test for antidepressants, Archives Internationales de Pharmacodynamie et de Therapie, 1977, 229(3): 327-36.

[36] Wasana Pratchayasakul, Anchalee Pongchaidecha, Nipon Chattipakorn and Siriporn Chattipakorn, Ethnobotany \& ethnopharmacology of Tabernaemontana Divaricata,2008, Indian J Med Res, 127: 317335.

[37] Verma A., Jana G.K., Sen S., Chakraborty R., Sachan S. And Mishra A., Pharmacological Evaluation of Saraca indica Leaves for Central Nervous System Depressant Activity in Mice, Journal of Pharmaceutical Sciences and Research, 2010, 2:338-343.

[38] Bhattacharya S.K., Satyan K.S., Experimental methods for evaluation of psychotropic agents in rodents: Anti-anxiety agents,Indian Journal of Experimental Biology, 1997, 35:565-575.

Citation: M. Faruq et al., "Central Nervous System Depressant Effects of the Methanolic Leaves Extracts of Tabernaemontana divaricata", International Journal of Medicinal Plants and Natural Products (IJMPNP), vol. 4, no. 1, pp. 1-7, 2018. http://dx.doi.org/10.20431/2454-7999.0401001

Copyright: () 2018 Authors. This is an open-access article distributed under the terms of the Creative Commons Attribution License, which permits unrestricted use, distribution, and reproduction in any medium, provided the original author and source are credited. 